\title{
ANALYSIS OF E-LEARNING PROBLEMS DURING COVID-19 PANDEMIC
}

\author{
Duha Hardiyanti Awalia*, Dadi Setiadi, and Kusmiyati \\ Biology Education Deparment, FKIP University of Mataram, Mataram, Indonesia \\ *Email: duhahardiyantiawalia17@gmail.com
}

Accepted: October, 29 2021. Approved: November, 12 2021. Published: November, 172021

\begin{abstract}
The occurrence of the Covid-19 outbreak requires the implementation of distance learning by implementing a learning system such as e-learning. There must be problems during the learning process using elearning. The purpose of the research is to describe the difficulties of e-learning during the Covid-19 pandemic for class X students at SMAN 1 Keruak. The population in this study was all students in the class of X IPA SMAN 1 Keruak, divided into four courses with 120 people. The sample was taken randomly. The research method used is a descriptive research method with a qualitative approach. The research results in e-learning were carried out in 3 stages, namely learning planning, learning process, and evaluation. Students experienced difficulties in the e-learning learning process during the Covid-19 pandemic regarding the readiness of educational institutions, internet connection, internet packages, inadequate devices, and obstacles to understanding the material. During implementing e-learning, students experienced difficulties with the highest percentage of $78 \%$. Based on these results, it can be stated that students experienced difficulties in the e-learning process during the Covid-19 pandemic regarding facilities and infrastructure.
\end{abstract}

Keywords: learning problems, e-learning, covid-19

\section{INTRODUCTION}

The use of smartphones and the internet at junior and high school levels strongly supports the implementation Curriculum of 2013 as demanded by the government. Educators should optimize the use of technology during the learning process [1]. The term e-learning is more likely intended to transform the learning process in schools or universities into a digital form bridged by internet technology. E-learning contains all information so that each individual can filter the news [3].

E-learning emphasizes using technology to provide a series of solutions to improve knowledge and skills [4]. Applying e-learning in the teachinglearning process must have both advantages and disadvantages. There are several advantages to using e-learning, one of which is time flexibility. One of the disadvantages that students should be aware of is having a good connection [5]. [6] There are several vital conditions in e-learning: 1) the availability of a learning platform service to support students; 2) a tutor or consultant to help students if they experience difficulties during the process. There are two types of e-learning [7]: 1) Synchronous Training, which means simultaneously. The learning process occurs at the same time between educators and students.

2) Asynchronous means that students have access to the learning material with no limits of space and time. Students can carry out the learning process and complete it at any time according to a predetermined schedule.

E-learning can be divided into three models [8], namely: 1) Adjunct model, this model can be regarded as a traditional learning process supported by an online delivery system as a statement. 2) Mixed/Blended Model, the online delivery system as an inseparable part of the overall learning process. It means that both the face-to-face process and online learning are unified. 3) Fully Online Model, in this model, all learning interactions and delivery of learning materials occur online. The implementation of distance learning during the Covid-19 emergency is by implementing the Home Learning system or studying at home. Various unconventional methods, such as assignments, independent projects, and others, can be chosen by using multiple learning media such as e-learning, Google zoom, and other applications [9].

The results of the interview with the curriculum vice-principal of SMAN 1 Keruak, there were several obstacles faced by the students at the beginning of implementing the e-learning system, especially when students participated in the online learning. Many students didn't respond to the teachers during the process. Besides, most of the teachers didn't come to school when the online learning took place, even when they were obliged to go to school with teaching schedules. Besides those, the school also experienced infrastructure problems in implementing e-learning.

\section{RESEARCH METHODS}

The research implements descriptive research with a qualitative approach. The study took place in SMAN 1 Keruak, held in the second semester in the academic year of 2020/2021. The study population was all X IPA students of SMAN 1 Keruak, with 120 students. The sampling technique used was simple random sampling. The type of data used in the study was primary data, such as interviews and questionnaires. The questionnaire used in the form is structured questions with alternative answers. The instrument of the questionnaires uses a Likert scale with a range of 1-4 such as: 
Table 1. Likert Scale Questionnaire Qualification Score

\begin{tabular}{cc}
\hline Answer Choices & Scores \\
\hline 1 & Strongly disagree \\
& (STS) \\
2 & Disagree (TS) \\
3 & Agree (S) \\
4 & Strongly agree (SS) \\
\hline
\end{tabular}

Secondary data such as school documents related to the focus of the study includes the principal, viceprincipals, biology teacher of X grade and students of XIPA. The data analysis was carried out by data reduction, data presentation, and verification. The data analysis of the questionnaire was carried out by outlining the quantitative data in the form of a percentage of each provided an alternative answer. The respondents' questionnaire analysis was calculated using the following formula:

Description

$$
\mathrm{P}=\frac{n}{N} X 100
$$

$\mathrm{P}=$ percentage of assessment $(\%)$

$\mathrm{n}=$ total score obtained

$\mathrm{N}=$ total maximum score

Based on the calculation of the results percentage of the questionnaire on the difficulty of e-learning after being converted with the following conditions:

Table 2. Student learning difficulty level

\begin{tabular}{ccc}
\hline $\begin{array}{c}\text { Value } \\
\text { criteria }\end{array}$ & Percentage \% & Category \\
\hline 4 & $75-100 \%$ & Very Difficult \\
3 & $51-75 \%$ & Difficult \\
2 & $26-50 \%$ & Fairly Difficult \\
1 & $0-25 \%$ & Not Difficult \\
\hline
\end{tabular}

The presentation of the diagram data used descriptive analysis to calculate the average and standard deviation. The validity of the data was checked by testing the reliability and certainty.

\section{RESULTS AND DISCUSSION \\ Description of E-learning Learning Plan}

Planning e-learning to the learning program is about how the schools respond to the policy. Based on the interview results from the biology teacher of class X IPA, "e-learning learning planning is carried out by giving special training related to e-learning through WAG." The curriculum vice principal also expressed the same thing: "The first step in planning e-learning lessons at SMAN 1 Keruak was carried out by giving the training provided by the school to teachers and the curriculum team. The training provided by the school is usually attended by all teachers with instructors from the school".

\section{Description of E-learning Implementation}

In implementing e-learning, the delivery of material or core activities usually uses WhatsApp, LKS books, and learning videos sent via WhatsApp groups. Students are then asked to access learning videos independently and listen to the videos. Biology teacher of SMAN 1 Keruak also stated the same thing, "The learning process is carried out at SMAN 1 Keruak mostly uses WhatsApp application since it is generally easier to be accessed both by students and teachers". Some of the students also stated the learning process is carried out using WhatsApp. The teachers also provide learning media such as books and worksheets, which Whatsapp Group sent. According to the interview results with the SMAN 1 Keruak, the school also experienced problems during the e-learning case of facilities and infrastructure. The major problem is the lack of internet connection. Some students can get the task done if the internet connection is stable enough, and the other way around for students who don't have a stable internet connection, such as 24 students who live in Maringkik Island. The place is prone to signal and often experiences power failure due to strong wind. Overcoming the problems, the school held a visiting teacher program. Another solution that the school provides is giving quota vouchers to participate in e-learning.

The Biology teacher also stated that students' obstacle in the e-learning learning process mostly is the unstable internet connection. So that school combines e-learning with the natural learning process, expected to facilitate students in the learning process, especially during this Covid-19 pandemic. Meanwhile, the vice-principal stated that the teachers' obstacles in e-learning are due to the lack of preparation of learning materials making the material unattractive and tending to be monotonous. It will significantly impact the students' understanding of the material itself. On the other hand, most students complained about internet quotas, network connection, and inactivity. Out of $89.70 \%$ was active at first and continued decreasing to $40-50 \%$. This problem led the school to come into the policy to collaborate between online and offline learning systems with a strict health protocol to carry during the implementation. As for the students, they struggle to find places with a good connection.

The comparison recapitulation of the percentage of students' responses to the difficulties experienced during the e-learning process based on the alternative answers can be illustrated in the following diagram. 


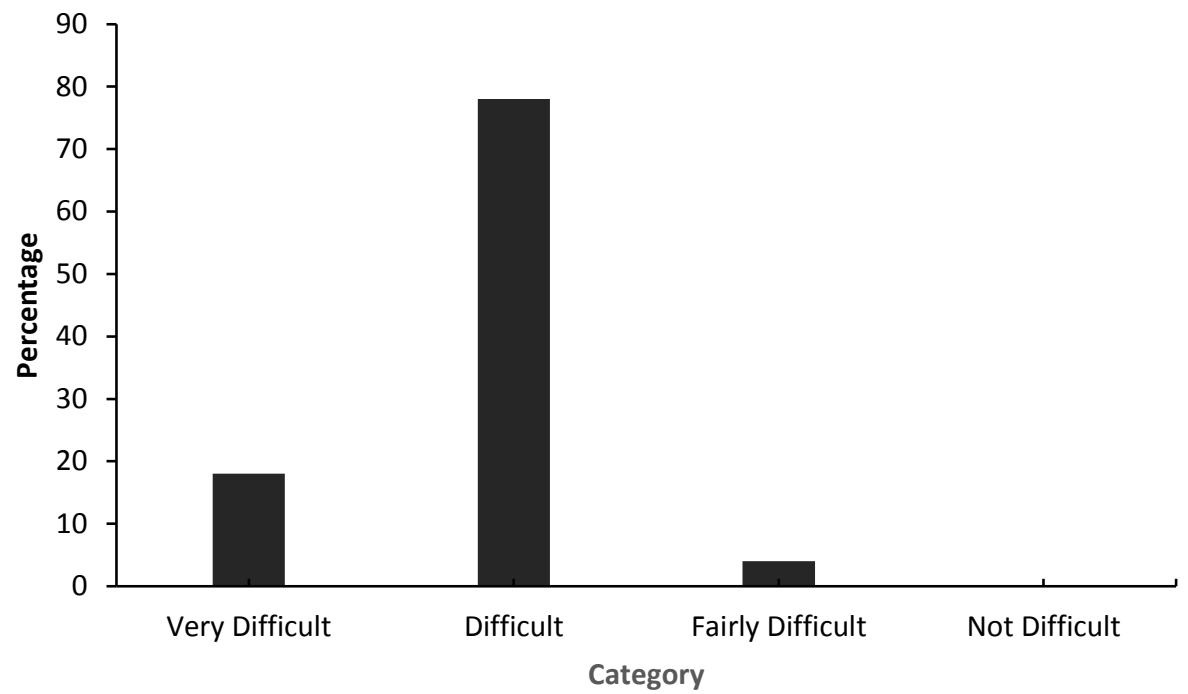

Figure 1. The percentage of students having difficulties in E-learning

Based on the Figure above, it can be interpreted that the highest average was $78 \%$, in which 48 students chose the category of difficult, $18 \%$ consist of 11 students chose the category of very difficult, $4 \%$ consist of 2 students selected the category of moderate difficulty. In contrast, no students chose the category of not difficult.

\section{Description of E-learning Evaluation}

The learning evaluation was carried out by giving a written assignment and multiple choices. The essay question is referred to evaluating the skill aspect while the multiple-choice is referred to assessing the knowledge aspect, the assignment submitted in Google drive. The biology teacher stated that "I usually give questions at the end of the lesson also both individual and group tasks. The process is evaluated through the structured assignment as to how it was done during the normal learning". The students justified the statement that they were given a chance to propose questions related to the material. Evaluating the learning process is highly beneficial to assess in-depth the students' understanding and to which point the goals have already been set to assess the change of attitudes during the e-learning. The current condition of COVID-19 requires the teachers to direct the students to innovate and change the learning pattern that was originally set to be face-to-face into online learning [10]

E-learning is an alternative solution during the Covid-19 pandemic so that the teaching and learning activities can still take place [11]. Teachers can provide the material, and students can learn from home. Facilities and infrastructures are crucial when heavily relying on information technology [12]. Elearning enables students and teachers to interact with network connections [13]. Implementation of elearning requires the support of mobile devices such as smartphones, laptops, and computers, which are used to access information with no limits of space and time [14].

E-learning implantation at SMAN 1 Keruak applies the type of synchronous training in which students and teachers interact with one another at the same time using video conferences or chatting rooms. Due to the limitation of the face-to-face learning at SMAN 1 Keruak, the school applies $e$ learning with a model of fully online e-learning to all kinds of learning interaction and material delivery.

The difficulty students' experienced during the implementation of e-learning is mostly the supporting facilities such as network and internet quotas. According to [15], educational facilities are the equipment that supports learning directly, while the educational infrastructures are the equipment that does not directly help the learning process. The elearning process held at SMAN 1 Keruak mainly uses WhatsApp as stated in [16] that "The presence of WhatsApp facilitates both short and long-distance communication and is an oral and written communication tool which capable of storing message practically.

Based on the students' responses percentage to the alternative answers, most students responded that they faced difficulty during the e-learning learning process with the highest percentage of $78 \%$. It was because the learning process of elearning during the COVID-19 pandemic wasn't carried out optimally. The results of interview and documentation conducted on the principal, viceprincipals, biology teacher, and X IPA students of SMAN 1 Keruak found that the difficulties often experienced were namely: first, the readiness of educational institutions to implement an e-learningbased learning system during Covid-19 pandemic, Second, regarding the network, students come from various villages which mostly don't prone to the internet. It is in line with the study conducted by 
[17], which stated that technical difficulties in the form of signals and the inability to learn e-learning are the most common difficulties experienced by students. Most of the students complained that studying was troubling because of the unstable network and waste of internet quota.

Thirdly, not all students have internet quotas regarding internet quotas, which had been a significant obstacle in the process. Most of the students from middle to lower economic conditions [18] stated that students' family background and conditions highly impact the e-learning process. Most of the families complained about the implementation of e-learning because it cost them higher. Fourthly, inadequate devices have a significant impact, such as a laptop with a damaged WiFi device old smartphone which doesn't support a stable internet connection. Fifthly, the problems of understanding the material can be caused by several factors, such as the teachers' lack of material preparation. As for the students, it happened because students didn't participate in the e-learning comprehensively and might be caused due to students' issues such as their physical and psychological conditions when the e-learning process takes place. If the e-learning process is textbased, students are provided with learning material and questions to answer. Most students complained about this method because they couldn't understand the material itself. It is in line with the study [18] that all students do not necessarily understand the content of e-learning material. The learning material is packed in the form of an e-book arranged as a summary of the material. Students' incomprehensive understanding of the material leads to selfinterpretation. In addition, students don't have the same knowledge of the material.

There are several solutions offered in this study related to e-learning problems. Firstly, the change of the learning system due to the COVID-19 condition naturally brought significant impacts on how the teachers carry the learning process, related to the preparation of learning material, model, and method of the learning itself. It is common for teachers to experience difficulty using information technology so that the learning process can't work optimally. Thus, schools provide training regarding the learning process of e-learning to help teachers be adapted to the situation so that they can carry the learning process as to how it should be done.

The internet quotas and network provide a special internet quota to support the e-learning process. Internet conditions going to a stable network. Students can contact their teachers to notify them that they can't join the e-learning due to the network problem [19]. Students with network problems can get help from family members to have an internet connection. Students' participation in the educational program can also overcome this problem via televisions held by the Ministry of
Education and Culture. The program is created to facilitate students' learning process during the current condition.

As for the solution to inadequate devices, schools provide supporting devices for students who don't own smartphones. [20-22] Said that schools should provide students with a proper internet connection and supporting devices to solve the problems so the school's learning process can be carried out optimally. The student's understanding of the learning material can be preparing a wellprepared and attractive learnithel in the form of Power Point equipped with illustrations and videos related to the material to attract students to focus on the learning process.

In the case of using information technology, teachers can use a simple application in the learning process such as WhatsApp to send the learning material in the form of PowerPoint, audio, and video. [17] Stated that teachers can enrich the learning material and their teaching skills from YouTube, which nowadays provides learning material. Students tend to be more interested in participating in the learning process. Overcoming students' personal issues such as laziness and boredom can be done by creating a supportive condition at home as to how the students need it. For example, students participate was a comfortable and not noisy condition when in the learning process and ensure that students are in good health and ready to study.

\section{CONCLUSIONS}

Based on the data analysis and discussions, the e-learning learning problems in the pandemic era of COVID-19 are the institution readiness, network, internet quota, inadequate devices, and students' understanding of the material that has caused the learning process can't be carried out optimally. The solution to the problem is to provide facilities and infrastructures to support students in the e-learning learning process.

\section{REFERENCES}

[1] Ismanto, E., Novalia, M., \& Herlandy, P. B.(2017). Pembelajaran Bagi Guru SMA Negeri Kota Pekanbaru. Jurnal Untuk Mu NegeRI, 1(1), 42-47.

[2] Munir. (2009). Pembelajaran jarak jauh berbasis teknologi informasi dan komunikasi. Bandung: Alfabeta.

[3] Budiyanto, M., Elok, S \& Ahmad, Q. (2018). Pembelajaran Fisika Dasar Menggunakan ELearning Untuk Meningkatkan Literasi Sains Mahasiswa. Jurnal Penelitian Pendidikan IPA, 3(2): 82-86.

[4] Kamarga, H. (2002). Belajar Sejarah Melalui elearning Alternatif Mengakses Sumber Informasi. Jakarta: Inti Media.

[5] Effendi, E \&Hartono, Z. (2005). E-learning Konsep dan Aplikasi. Yogyakarta: Andi office. 
[6] Murtiyasa, B. 2012. Pemanfaatan Teknologi Informasi dan Komunikasi Untuk Meningkatkan Kualitas Pembelajaran Matematika. Surakarta: FKIP Univ.

[7] Wiwin, H.(2016).Penggunaan E-Learning Sebagai Media Pembelajaran. Jurnal Pendidikan Ekonomi, 1, 1-18.

[8] Prawiradilaga, D. S. (2007). Prinsip Disain Pembelajaran. Jakarta: Kencana Prenada.

[9] Wijaya, R., Mustika, L\&Dorris, Y. (2020). Dampak Pandemi Covid-19 Terhadap Pemanfaatan ELearning. Jurnal Dimensi, 9(2), 307-322.

[10]Zhafira, N. H., Ertika, Y., \& Chairiyaton, C. (2020). Persepsi Mahasiswa Terhadap Perkuliahan Daring Sebagai Sarana Pembelajaran. Jurnal Bisnis Dan Kajian Strategi Manajemen, 4(1), 37-47.

[11][11] Albab, S. U. 2020. Analisis Kendala Pembelajaran E-Learning Pada Era Disrupsi Di SMK Terpadu Al-Islahiyah Singosari Malang. Jurnal Manajemen Pendidikan, 2(1):47-57.

[12] Handarini, O. I. 2020. Pembelajaran Daring Sebagai Upaya Study From Home (SFH) Selama Pandemi Covid 19. Jurnal Pendidikan Administrasi Perkantoran (JPAP), 8(3):496-503.

[13] Kuntarto, E. (2017). Keefektifan Model Pembelajaran Daring Dalam Perkuliahan Bahasa Indonesia di Perguruan Tinggi. Jurnal Indonesian Language Education and Literature, 3(1), 99-110.

[14] Gikas, J., \& Grant, M. M. (2013). Perangkat Komputasi Seluler Di Perguruan Tinggi: Perspektif Mahasiswa Tentang Pembelajaran Dengan Ponsel, Ponsel Cerdas \& Media Sosial. Internet Dan Pendidikan Tinggi. 19: 18-26, diakses tanggal 21 Agustus 2021.

[15] Arifin, M.\&Barnawi. (2014). Manajemen Sarana dan Prasarana Sekolah. Jogjakarta: Ar-RuzzMedia.

[16] Suryadi,A.(2018). Pendidikan, Investasi SDM, dan Pembangunan: Isu, Teori, dan Aplikasi untuk Pembangunan Pendidikan dan Sumber Daya Manusia Indonesia, Edisi Kedua. Bandung: Widya Aksara Pres.

[17] Utami, E. W. (2020). Kendala dan Peran Orangtua dalam Pembelajaran Daring Pada Masa Pandemi Covid-19. Jurnal Seminar Nasional Pascasarjana, 472-478.

[18] Wahyuningsih, K.S. (2021). Problomatika Pembelajaran Daring Di Masa Pandemi Covid-19 Di SMA Dharma Praja Denpasar. Jurnal Pangkaja Program Pasca Serjana Universitas Hindu Negeri I Gusti Bagus Sugriwa Denpasar, 24(1), 1-7-118.
[19] Dokumen Surat Edaran Nomor 4 Tahun 2020 tentang Pelaksanaan Kebijakan Pendidikan Dalam Masa Darurat Penyebaran Coronavirus Disease (Covid-19) dalam format PDF ini ditandatangai oleh Menteri Pendidikan dan Kebudayaan Nadiem Makarim pada tanggal 24 Maret 2020, diakses tanggal 21 Agustus 2021.

[20] Kurniati, N., Sripatmi, S., Baidowi, B., \& Azmi, S. (2021). Pembelajaran Daring Kombinasi untuk Meningkatkan Hasil Belajar Mahasiswa pada Mata Kuliah Aljabar Abstrak. Jurnal Pijar Mipa, 16(3), 310-316.

[21] Syazali, M., Rahmatih, A. N., \& Nursaptini, N. (2021). Profil Keterampilan Proses Sains Mahasiswa Melalui Implementasi SPADA Unram. Jurnal Pijar Mipa, 16(1), 103-112.

[22] Syazali, M., Rahmatih, A. N., \& Nursaptini, N. (2021). Profil Keterampilan Proses Sains Mahasiswa Melalui Implementasi SPADA Unram. Jurnal Pijar Mipa, 16(1), 103-112. 